\title{
Biosurfactant production by fungi as a sustainable alternative
}

\section{Produção de biossurfactantes por fungos como uma alternativa sustentável}

\author{
Artemisia Carla Santos da Silva ${ }^{1}$, Patrícia Nunes dos Santos ${ }^{1}$, Thayse Alves Lima e Silva', \\ Rosileide Fontenele Silva Andrade', Galba Maria Campos-Takaki 1* (D)
}

\begin{abstract}
A wide variety of bacteria is far more exploited than fungi as biosurfactants (BS) or bioemulsifiers (BE), using renewable sources. BS are considered to be environmentally safe and offer advantages over synthetic surfactants. However, the BS yield depends largely on the metabolic pathways of the microorganisms and the nutritional medium. The production of BS or BE uses several cultural conditions, in which a small change in carbon and nitrogen sources affects the quantity of BS or BE produced. The type and quantity of microbial BS or BE produced depend mainly on the producer organism, and factors such as carbon and nitrogen sources, trace elements, temperature and aeration. The diversity of BS or BE makes it interesting to apply them in the pharmaceutical and cosmetics industries, agriculture, public health, food processes, detergents, when treating oily residues, environmental pollution control and bioremediation. Thus, this paper reviews and addresses the biotechnological potential of yeasts and filamentous fungi for producing, characterizing and applying $\mathrm{BS}$ or BE.
\end{abstract}

KEYWORDS: surface active compounds; agroindustrial substrates; fungi; amphiphilic molecules.
RESUMO: Uma grande variedade de espécies bacterianas é bem mais explorada que os fungos como agentes biossurfactantes (BS) ou bioemulsificantes (BE), usando fontes renováveis. Os BS são considerados ecologicamente seguros e oferecem vantagens sobre os surfactantes sintéticos. Entretanto o rendimento de BS depende grandemente das vias metabólicas dos micro-organismos e do meio nutricional. A produção de $\mathrm{BS}$ ou $\mathrm{BE}$ utiliza várias condiçôes culturais, em que uma pequena alteração nas fontes de carbono e nitrogênio afeta a produçáo de BS. O tipo e a quantidade de $\mathrm{BS}$ ou $\mathrm{BE}$ microbianos produzidos dependem principalmente do organismo produtor e de fatores como fontes de carbono e nitrogênio, oligoelementos, temperatura e aeração. A diversidade de BS ou BE torna-os interessantes para aplicação nos campos farmacêutico, cosmético, da agricultura, da saúde pública, em processos alimentares, detergentes, no tratamento de resíduos oleosos, no controle de poluição ambiental e na biorremediação. Assim, a presente revisão aborda o potencial biotecnológico de leveduras e fungos filamentosos para produção, caracterizaçáo e aplicaçóes de BS ou BE.

PALAVRAS-CHAVE: compostos de superfícies ativas; substratos agroindustriais; fungos; moléculas anfifílicas. 


\section{INTRODUCTION}

Surfactants are chemical compounds, characterized by the presence of amphipathic molecules consisting of hydrophobic and hydrophilic moieties, which are partitioned preferentially at the interface between fluid phases with different degrees of polarity and hydrogen bonds. Thus, they reduce surface and interfacial tension, and form microemulsions, in which hydrocarbons can solubilize. The polar portion (head) may be ionic (cationic or anionic), nonionic and amphoteric, while the apolar portion often consists of hydrocarbons and can be solubilized in water (CALVO et al., 2009). Therefore, biosurfactants (BS) or bioemulsifiers (BE) are considered the most versatile chemical groups of amphipathic molecules possessing hydrophobic and hydrophilic domains used in various industrial processes. As they have to compete in the market, however, it is essential to produce $\mathrm{BS}$ or BE that are eco-friendly and to do so economically (DESAI; BANAT, 1997; PRADHAN, 2017; BHATTACHARYA et al., 2017).

$\mathrm{BS}$ and $\mathrm{BE}$ are amphipathic compounds produced by various microorganisms, and have unique properties, e.g., they are lipophilic and hydrophilic. Their extremities have opposing polarities, represented by an apolar and a polar head. BS or BE accumulate in the air-water and oil-water interfaces and surface (MUTHUSAMY et al., 2008). The main properties of these compounds are: they reduce surface and interfacial tensions; they have hydrophilicity actions; they are ecologically correct and non-toxic; they retain their functionality under extreme conditions of $\mathrm{pH}$ and temperature, stability, wettability and dispersion (KOSARIC, 2001). In this context, the large chemical diversity and diverse properties demonstrate that BS can be applied across a wide range of activities, such as biodegradation, emulsification, de-emulsification, and solubilization. They can be produced from renewable sources, and they both remain effective under extreme conditions of $\mathrm{pH}$, salinity and temperature. The $\mathrm{BS}$ and $\mathrm{BE}$ were more advantageous than the chemical surfactants The microbial BS produced in cold habitats provide a perspective on the most promising future applications (BANAT et al., 2000; PERFUMO et al., 2018).

The $\mathrm{BS}$ or $\mathrm{BE}$ are classified according to their chemical composition, molecular weight, physicochemical properties, mode of action and microbial origin. For example, those of low molecular weight are fatty acids, glycolipids, cyclic and acyclic lipopeptides, and those of high molecular weight are polysaccharides amphipathic, proteins, lipopolysaccharides, lipoproteins, polymeric and vesicles and microbial cells with surfactant activity, which are classified as particulate biosurfactants. Thus, low molecular weight BS are efficient at reducing surface and interfacial tensions, while high molecular weight $\mathrm{BE}$ are more effective in stabilizing oil-in-water emulsions (CALVO et al., 2009; DESAI; BANAT, 1997; RAJESH et al., 2017).

In the present study, it was found that BS or BE were produced by bacteria (KOMA et al., 2001; KREPSKY et al., 2007;
RAJESH et al., 2017; BOUASSIDA et al., 2018), followed by yeasts (SARUBBO et al., 2001; 2006; 2007; VANCE-HARROP et al., 2003; AMARAL et al., 2008; KATEMAI, 2012), and rarely by filamentous fungi (BATRAKOV et al., 2001; 2003; KATEMAI et al., 2008; KIRAN et al., 2009; SILVA et al., 2014; 2015; PELE et al., 2018).

Natural BS or BE produced by bacteria have been exploited a lot - those produced by yeast a little less, while research studies on filamentous fungi are rare. However, the few filamentous fungi exploited have shown potential to produce $\mathrm{BS}$ or $\mathrm{BE}$, with higher yields when compared to those from yeasts, but mainly when compared to those from bacteria (BHARDWAJ et al., 2013). Therefore, the release of high amounts of BS produced by filamentous fungi has been attributed to cell wall stiffness, as suggested by KIM et al. (2002; 2006).

Thus, this paper reviews and addresses the biotechnological potential of filamentous fungi for producing BS or BE, considering the high industrial potential of these organisms, as described by CASTIGLIONI et al. (2009), PELE et al. (2018), and SILVA et al. (2014). In addition, using filamentous fungi meets the demands of society for concerns about the environment to be taken into account. This is also reflected in the new legislation and prompts the search for products obtained via microbial, toxicity-free alternatives, rather than depending on commercial surfactants synthesized from petroleum.

Therefore, this paper generates perspectives on how to face the challenges, especially the need to increase knowledge about biochemical pathways of BS or BE production and to assess the biotechnological potential of fungi (yeasts and filamentous fungi) for producing BS or BE. They are a versatile alternative, and it includes the sustainable use of agricultural by-products in the search for new surfactants with wide applicability and which cost less to produce is included. Therefore, this paper indicates the main challenges and the need to increase knowledge about the biochemical pathways of BS production, associated with the biotechnological potential of yeasts and filamentous fungi.

Thus, a versatile and sustainable alternative is presented, considering the high enzymatic capacity of using agricultural and industrial by-products to produce new BS or BE, besides which molecules can be applied widely and reduce production costs. Table 1 shows the studies performed with yeasts, the genera and species most studied, as well as the class of BS, and which biosurfactant is synthesized.

It is observed that most yeasts of the genus Candida are the most investigated among different types of $\mathrm{BS}$ or $\mathrm{BE}$ that have the potential to be produced economically. It is possible that the broader use of yeast to produce these substances with great success is related mainly to its GRAS status (generally considered as safe). Microorganisms that have a GRAS status do not present a risk of inducing toxicity and pathogenic reactions (FONTES et al., 2008). In addition, the versatility of the metabolic pathways of yeast, especially Yarrowia lipolytica, and the perfect stage of Candida lipolytica, both yeasts considered to have unconventional 
metabolism, is highlighted in view of its growth in a wide variety of substrates with different chemical natures to produce BS and/ or in bioremediation (HUA et al., 2003; LANCIOTTI et al., 2005; AMARAL et al., 2010; CAMPOS-TAKAKI et al., 2010; RUFINO et al., 2014; AGHAJANI et al., 2018).

It should be noted that filamentous fungi (Table 2) are less exploited than yeasts, due to their slower growth.
However, they are excellent producers of BS or BE, as well as emulsifiers, with stable emulsions, and have an excellent capacity to reduce stress. Moreover, they promote the dispersion of hydrophobic compounds, which enables them to be applied in different sectors (SILVA et al., 2014; SOUZA AF et al., 2016; SOUZA PM et al., 2016; 2017b; PELE et al., 2018).

Table 1. Types of biosurfactants or bioemulsifiers produced by yeasts according to the classification.

\begin{tabular}{|c|c|c|}
\hline Biosurfactant & Microorganism & References \\
\hline \multirow{9}{*}{ Glycolipids } & Candida bombicola & Solaiman et al. (2004) \\
\hline & Candida bombicola & Roelants et al. (2013) \\
\hline & Candida bogoriensis & Kitamoto et al. (2001) \\
\hline & Candida sphaerica UCP0995 & Sobrinho et al. (2008) \\
\hline & Candida glabrata & Andrade et al. (2015) \\
\hline & Candida ishiwadae & Thanomsub et al. (2004) \\
\hline & Candida batistae & Konishi et al. (2008) \\
\hline & Pseudozima fusifornata & Morita et al. (2007) \\
\hline & Wickerhamomyces anomalus CCMA 0358 & Souza KST et al. (2017) \\
\hline \multirow{10}{*}{ Sophorolipids } & Pseudozyma aphidis & Rau et al. (2005) \\
\hline & Candida bombicola & Casas; Ochoa (1999) \\
\hline & Candida bombicola & Cavalero; Cooper (2003) \\
\hline & Torulopsis petrophilum & Cooper; Paddock (1983) \\
\hline & Candida (Torulopsis) apicola & Hommel et al. (1994) \\
\hline & Candida bogoriensis & Tulloch et al. (1968) \\
\hline & Candida antarctica & Kim et al. (2002) \\
\hline & Pseudozyma rugulosa & Fukuoka et al. (2007a; 2007b) \\
\hline & Candida sp. SY16 & Kim et al. (2006) \\
\hline & Kurtzmanomyces sp. & Kakugawa et al. (2002) \\
\hline \multirow{9}{*}{ Complex Carbohydrates/protein/lipids } & Candida lipolytica UCPO988 & Sarubbo et al. (2007) \\
\hline & Candida lipolytica IA 1055 & Sarubbo et al. (2001) \\
\hline & Yarrowia lipolytica NCIM 3589 & Zinjarde et al. (1997) \\
\hline & Debaryomyces polymorphus & Singh; Desai (1989) \\
\hline & Candida tropicalis & Singh; Desai (1989) \\
\hline & Candida ingens & Amézcua-Vega et al. (2007) \\
\hline & Candida utilis & Shepherd et al. (1995) \\
\hline & Candida valida & Shepherd et al. (1995) \\
\hline & Candida boleticota & Mossa et al. (2006) \\
\hline \multirow{6}{*}{ Complex Carbohydrate /protein } & Candida lipolytica ATCC8662 & Cirigliano; Carman (1984; 1985) \\
\hline & Saccharomyces cerevisiae & Cameron et al. (1988); Bahia et al. (2018) \\
\hline & Kluyveromyces marxianus & Lukondeh et al. (2003) \\
\hline & Candida utilis & Sheperd et al. (1995) \\
\hline & Candida ingens & Amézcua-Vega et al. (2007) \\
\hline & Rhodotorula glutinis & Yoon; Rhee (1983) \\
\hline Lipopeptide & Candida glabrata & Morita et al. (2007) \\
\hline
\end{tabular}

Source: adapted from: Amaral et al. (2008; 2010); Campos-Takaki et al. (2010); Katemai (2012); Bhardwaj et al. (2013). 


\section{Influence of physico-chemical parameters on the production of biosurfactants or bioemulsifiers}

The BS or BE synthesis may be spontaneous or induced by the presence of lipophilic compounds, temperature variations, $\mathrm{pH}$, agitation speed, stress and low concentrations of the nitrogen source. Probably the main source for synthesis of BS or $\mathrm{BE}$ is the carbohydrate in the culture medium. The flow of this source regulates both the glycolytic and lipogenic pathways that act to form the hydrophilic portion (head) and the lipid part (tail), depending on the nature of the substrates (SYLDATK; WAGNER 1987; FONTES et al., 2008; 2012) (Fig. 1). However, the carbon sources that influence the production of BS or BE by different strains of microorganisms have been the subject of several studies. Although the production of BS or BE occurs in the presence of water-soluble carbon sources, such as sugars, several studies show that the highest $\mathrm{BS}$ or BE production is obtained when hydrophobic substrates are added (KALYANI et al., 2014).

It is observed in Figure 1 that, when a hydrocarbon is used as a carbon source, microbial metabolism mainly uses the lipolytic pathway and gluconeogenesis (formation of glucose from precursors other than hexoses) that can be used in the production of fatty acids or saccharides. Thus, the production of saccharides is activated by the gluconeogenesis pathway. Oxidation of fatty acids occurs via $\beta$-oxidation with the formation of acetyl coenzyme A (acetyl-CoA) or propionyl coenzyme A (propionyl-CoA), in the case of odd-chain fatty acids. From the formation of acetyl-CoA, the reactions involved in the synthesis of polysaccharide precursors, such as glucose 6-phosphate, are essentially the inverse of those involved in glycolysis. However, the reactions catalyzed by pyruvate kinase and phosphofructokinase- 1 are irreversible; therefore, other enzymes, which are unique to gluconeogenesis, are required to bypass such reactions. The main reactions are shown in Figure 2, until the formation of glucose 6-phosphate, as the main precursor of the polysaccharides, disaccharides to be formed to produce the hydrophilic portion of the glycolipids (SYLDATK; WAGNER, 1987; OCHSNER et al., 1994; FONTES et al., 2008; 2012).
The biosynthesis of the emulsifier can take place in the synthesis of the head - hydrophilic portion (carbohydrate) and the hydrophobic part (lipids), whereas the lipid chain length will depend on the carbonic substrate present in the medium (Fig. 2). The authors described in this study that the carbohydrate and lipid syntheses depend on the chemical nature of the substrates used (SYLDATK; WAGNER, 1987; FONTES et al., 2008; 2012).

\section{The effective cost of biosurfactant or bioemulsifier productions}

The literature affirms the economic stand point of BS or BE is not yet competitive with the synthetic surfactants obtained from petroleum (RUFINO et al., 2011).

Table 3 describes the renewable substrates used to BS or $\mathrm{BE}$ productions. However, the use of these biomolecules BS and $\mathrm{BE}$ is limited since the cost of production is high, and the production potential is low (PACWA-PLOCINICZAK et al., 2011; LUNA et al., 2009; 2013).

In order to raise the productivity of $\mathrm{BS}$ or $\mathrm{BE}$, several investigations described the successful of these active molecules production depends on the use of renewable substrates from biotechnological processes, as it cuts total costs by around $50 \%$. Despite of that, the purification process is considering another obstacle to producing these compounds from microbial origin (BANAT et al., 2010; 2014; ROCHA E SILVA et al., 2014).

$\mathrm{BS}$ or BE are considered extracellular secondary metabolites or associated with the cell membrane, the structure of which depends on the ratio of carbon and nitrogen sources. In this case, the BS or BE can be replaced by synthetic surfactants if the cost of the raw material reduces the cost of production (SILVA et al., 2014; ROCHA E SILVA et al., 2014).

\section{Methods of extraction and characterization of biosurfactants or emulsifiers}

The methods for extracting BS are variable and depend on the structure and chemical composition of the BS (MUTHUSAMY

Table 2. Types of biosurfactants or bioemulsifiers produced by filamentous fungi.

\begin{tabular}{lcc}
\hline Biosurfactant & Microorganism & Reference \\
\hline Lipopeptide & Penicillium chrysogenum SNP5 & Gautam et al. (2014) \\
\hline Glycolipid & Aspergillus niger & Kannahi; Sherley (2012) \\
\hline Complex Carbohydrate/protein/lipid & Cunninghamella echinulata & Silva et al. (2014) \\
\hline & Fusarium sp. & Qazi et al. (2014) \\
& Fusarium, Penicillium and Trichoderma & Castillo-Méndez et al. (2017) \\
\hline *Not identified & Aspergillus spp. & Cavalcanti et al. (2017) \\
& Aspergillus niger & Silva et al. (2015) \\
\cline { 2 - 3 } & Aspergillus fumigatus & Castiglioni et al. (2009) \\
\hline
\end{tabular}


et al., 2008), as shown in Table 4. The most used methods are precipitation (acidic, ammonium sulphate) and extraction with organic solvents (methanol, chloroform, ethanol and their associations) (LUNA et al, 2009, 2013; CHEN, 2012; LIMA et al., 2017).

Precipitation is the most cited technique in the literature, and acidification, using hydrochloric acid (HCL), is common for extracting crude BS. This method consists of acidifying the cell free metabolic liquid to a $\mathrm{pH} 2-3$ value. Another method to isolate $\mathrm{BS}$ is using ammonium sulphate precipitation, which follows a protocol similar to that one of acid precipitation, with the differential of the need for sample dialysis to remove salt in the final process (ANTUNES et al., 2013). Organic solvents such as ethanol and acetone are also commonly used to extract BS and are still a method that favors the reuse of solvents (SILVA et al., 2014). On the other hand, extraction with organic solvents favors the high yield of biosurfactants. However, it is a time-consuming and costly process (MUTHUSAMY et al., 2008; ANDRADE et al., 2015).

The main methods to characterize surfactants, according to LIMA et al. (2017), feature:

- the ability to reduce surface and interfacial tension due to the formation of a molecular film;

- the ability to form stable macro and microemulsions of hydrocarbons in water or water in hydrocarbons;

- the formation of micelles;

- their antimicrobial properties.

Some authors describe the most important properties evaluated in the search for new and powerful BS for industrial application, for example: being able to reduce surface and interfacial tension, a critical micellar concentration (CMC), the ability to form emulsions and to maintain the stability of them (MUTHUSAMY et al., 2008; PACWA-PLOCINICZAK, et al., 2011; JAMAL et al., 2012).

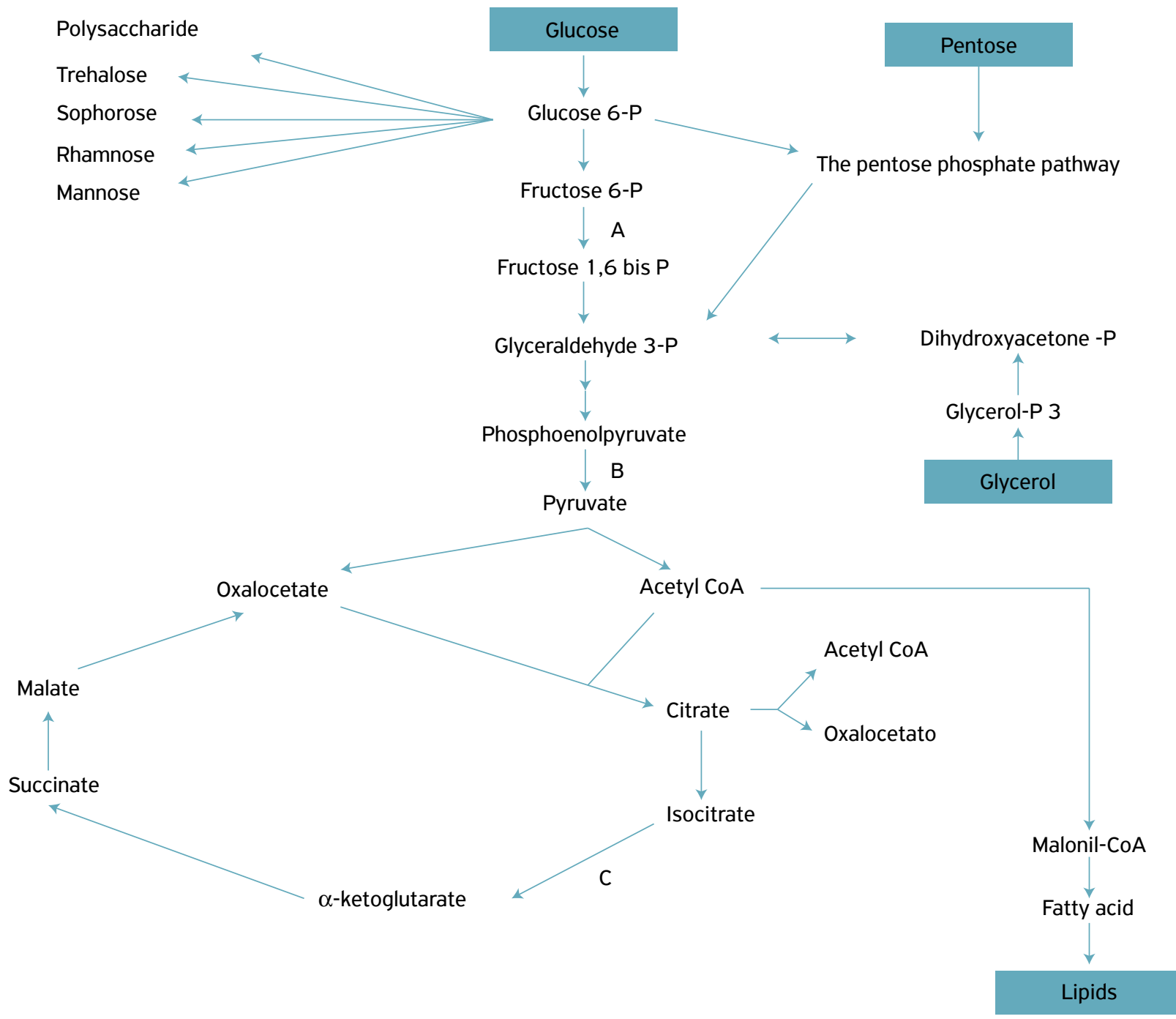

Acetyl-CoA: acetyl coenzyme A; Malonil-CoA: malonil coenzyme A

Figure 1. Intermediate metabolism related to the production of biosurfactant or bioemulsifier, using hydrophilic and hydrophobic sources as substrates, according to Fontes et al. (2008). 
Polysaccharide
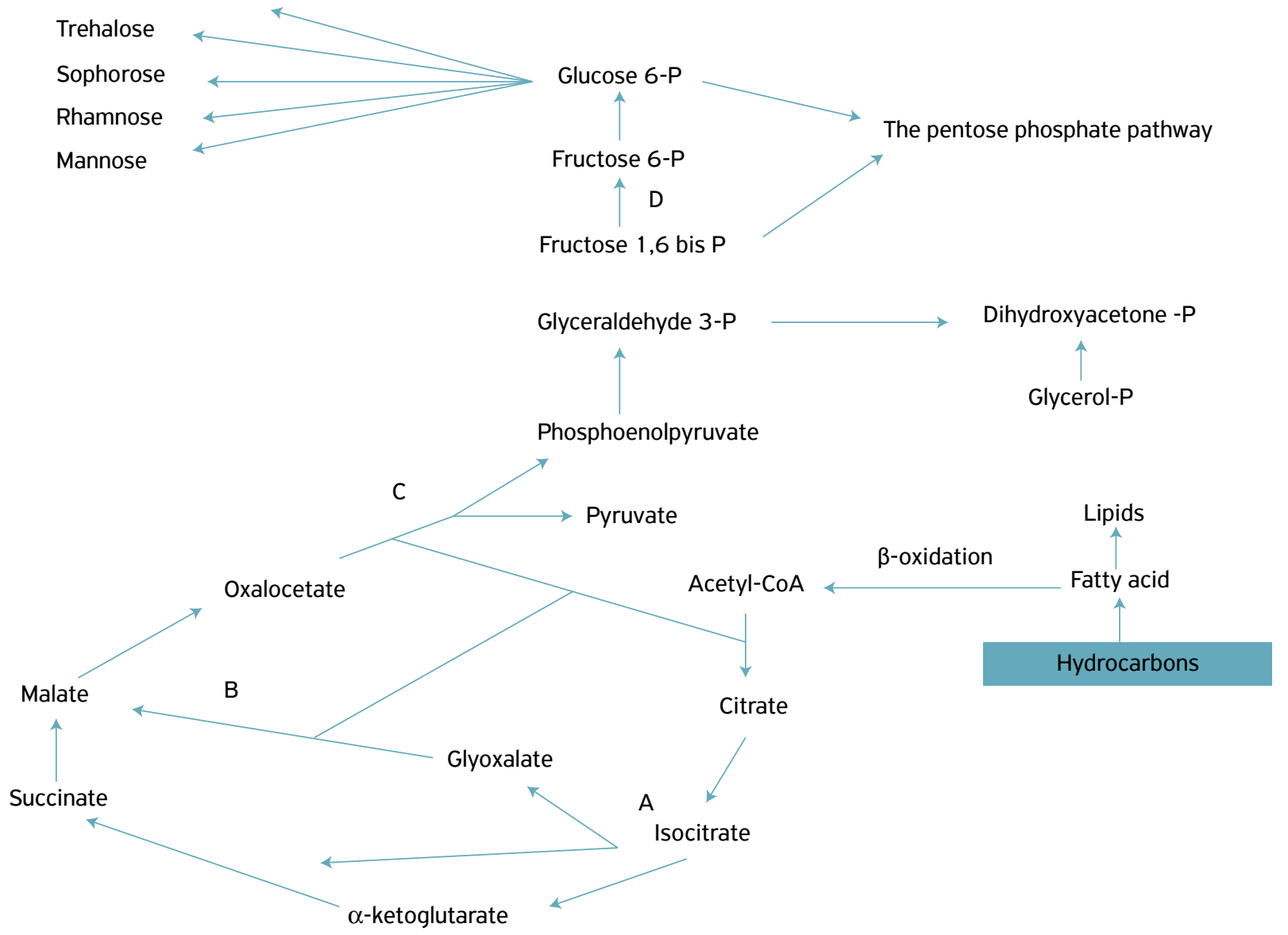

Figure 2. Intermediate metabolism related to the production of biosurfactant or bioemulsifier using hydrocarbons as substrates, according to Fontes et al. (2008).

Table 3. Renewable substrates as renewable sources for biosurfactant or bioemulsifier productions by yeasts or filamentous fungi.

\begin{tabular}{|c|c|c|}
\hline Microorganism & Renewable substrates & Reference \\
\hline Candida lipolytica & Canola oil/glucose & Sarubbo et al. (2007) \\
\hline Candida lipolytica & Industrial hydrophobic waste & Rufino et al. (2014) \\
\hline Candida lipolytica & Molasses & Karatay; Dönmez (2010) \\
\hline Candida lipolytica & Waste soybean oil and corn steep liquor & Souza PM et al. (2016) \\
\hline Candida sphaerica & Groundnut oil & Sobrinho et al. (2008) \\
\hline Cryptococcus curvatus & Acetate & Gong et al. (2015) \\
\hline Candida utilis & Corn oil & Shepherd et al. (1995) \\
\hline Candida glabrata & Cotton seed oil/glucose & Sarubbo et al. (2006) \\
\hline Candida glabrata & Corn steep liquor and whey & Lima et al. (2016; 2017) \\
\hline Candida glabrata & Corn steep liquor, whey and cassava waste water & Silva et al. (2017) \\
\hline Yarrowia lipolytica & Industrial glycerol & Papanikolaou et al. (2002) \\
\hline Yarrowia lipolytica & Crude glycerin and cashew apple juice & Fontes et al. (2012) \\
\hline Rhodotorula glutinis & Crude glycerol/Tween 20 & Saenge et al. (2011) \\
\hline Rhodotorula graminis & Corn steep solids/yeast extract & Galafassi et al.(2012) \\
\hline Ustilago maydis & Crude glycerol & Liu et al. (2011) \\
\hline Penicillium chrysogenum SNP5 & Wheat bran, grease waste & Gautam et al. (2014) \\
\hline Cunninghamella echinulata UCP & Soybean waste oil and corn steep liquor & Silva et al. (2014) \\
\hline Cunninghamella phaeosphora UCP 1303 & Post-fry soybean oil and corn steep liquor & Lins et al. (2017) \\
\hline Cunninghamella bertholletiae & Waste soy oil and corn steep liquor & Souza PM et al. (2017) \\
\hline Fusarium sp. & Sucrose and yeast extract & Qazi et al. (2014) \\
\hline Aspergillus fumigatus & Glycerol on solid state fermentation & Castiglioni et al. (2009) \\
\hline Rhizopus arrhizus & Soybean post-frying oil/sodium glutamate & Pele et al. (2018) \\
\hline
\end{tabular}




\section{Applications of biosurfactants}

The surface-active compounds produced by microorganisms have the potential to be applied, based on their functional properties, which include: emulsification, separation, wetting, solubilization, demulsification, inhibition of corrosion, and reduction of liquid viscosity and of surface tension. Thus, biosurfactants divide the interface between fluids with different degrees of polarity and hydrogen bonds such as air/water or oil/interfacial water. Therefore, due to these properties, biosurfactants are able to diminish the surface and interfacial tension and to form microemulsions, in which the hydrocarbons can be solubilized in water, or water emulsions can be formed using hydrocarbons. Therefore, BS of fungal origin have wide application and can be used in several industrial sectors that use chemical surfactants. Such industries include: petroleum, pharmaceuticals, cosmetics, agriculture with regard to formulating herbicides and pesticides, and the production of personal hygiene products and food processing, as described by NITSCHKE; PASTORE (2002), confirmed by the literature (Table 1), and presented in Table 5 (BANAT et al., 2000; BHARDWAJ et al., 2013; LIMA et al., 2016; 2017; SOUZA AF et al., 2016; SOUZA KST et al., 2017; AGHAJANI et al., 2018).

\section{CONCLUSION}

BS synthesized by yeast are the most studied, while there are not many studies on BS production by filamentous fungi. However, microorganisms isolated from soils, mangrove sediments and contaminated areas demonstrate excellent production potential, as well as the metabolic ability to use renewable substrates to produce high value surfactants and $\mathrm{BE}$.

The components of culture media, especially carbon sources, for the production of BS are divided into three categories: carbohydrates, hydrocarbons and vegetable oils. BS can be extracted, recovered and characterized by simple and low cost techniques. Therefore, using BS produced by fungi from renewable sources becomes a versatile and sustainable alternative that should be encouraged, in view of society's demands for ecologically safe products obtained through green technologies.

\section{ACKNOWLEDGMENTS}

The authors thank National Council of Scientific and Technological Development (Conselho Nacional de Desenvolvimento Científico e Tecnológico - CNPq), Foundation of Support to the Science and Technology of Pernambuco (Fundação de Amparo à Ciência e Tecnologia de Pernambuco - FACEPE), and Coordination for the Improvement of Higher Education Personnel (Coordenaçáo de Aperfeiçoamento de Pessoal de Nível Superior - CAPES), for financial support and the fellowships for the training of human resources.

Table 5. Functions and applications of biosurfactants.

\begin{tabular}{|c|c|}
\hline Functions & Fields of applications \\
\hline $\begin{array}{l}\text { Emulsification and } \\
\text { dispersants }\end{array}$ & $\begin{array}{l}\text { Cosmetics, paints, } \\
\text { bioremediation, oils and food }\end{array}$ \\
\hline Solubilizer & $\begin{array}{l}\text { Pharmaceutical and } \\
\text { hygiene products }\end{array}$ \\
\hline $\begin{array}{l}\text { Wetting and } \\
\text { penetrating agents }\end{array}$ & $\begin{array}{l}\text { Pharmaceutical, textile } \\
\text { and paint products }\end{array}$ \\
\hline Detergents & $\begin{array}{l}\text { Cleaning products, } \\
\text { agriculture }\end{array}$ \\
\hline Foaming agent & $\begin{array}{l}\text { Hygiene products, cosmetics } \\
\text { and flotation of ores }\end{array}$ \\
\hline Thickening agents & Paints and food \\
\hline Metal sequestrants & Mining \\
\hline Vesicle formers & $\begin{array}{l}\text { Cosmetics and drug } \\
\text { delivery system }\end{array}$ \\
\hline Microbial grow factor & Treatment of oily residues \\
\hline Demulsifiers & $\begin{array}{l}\text { Waste treatment, } \\
\text { oil recovery }\end{array}$ \\
\hline Viscosity reducers & $\begin{array}{l}\text { Transportation in } \\
\text { pipelines, pipelines }\end{array}$ \\
\hline Dispersants & $\begin{array}{c}\text { Coal-water, } \\
\text { lime-water mixtures }\end{array}$ \\
\hline Fungicide & $\begin{array}{c}\text { Biological control of } \\
\text { phytopathogens }\end{array}$ \\
\hline Recovery agent & Tertiary oil recovery (MEOR) \\
\hline
\end{tabular}

MEOR: microbial enhanced oil recovery. Source: Nitschke; Pastore (2002).

Table 4. Extraction methods related to the properties of biosurfactants

\begin{tabular}{lrr} 
Extraction methods & Properties & Vantages \\
\hline Acid precipitation & Insoluble in low pH & Low cost, recuperation of crude biosurfactant \\
\hline Precipitation with ammonium sulphate & Higher content of protein & Eficient for polymeric biosurfactant \\
\hline Precipitation with ethanol/acetone & Soluble in organic solvent & Eficient for polymeric biosurfactant \\
\hline Extraction with organic solvent & Soluble in organic solvent & Recuperation of crude biosurfactant, partial purification \\
\hline
\end{tabular}



REFERENCES

AGHAJANI, M.; RAHIMPOUR, A.; AMANI, H.; TAHERZADEH, M.J. Rhamnolipid as new bio-agent for cleaning of ultrafiltration membrane fouled by whey. Engineering in Life Science, v. 18, n.5, p.272-280, 2018. DOI:10.1002/elsc.201700070

AMARAL, P.F.F.; DA SILVA, J.M.; LEHOCKY, M.; BARROS-TIMMONS, A.M.V.; COELHO, M.A.Z.; MARRUCHO, I.M.; COUTINHO, J.A.P. Production and characterization of a bioemulsifier from Yarrowia lipolytica. Process Biochemistry, v.41, n.8, p. 1894-1898, 2006. DOI: $10.1155 / 2010 / 821306$

AMARAL, P.F.; COELHO, M.A.; MARRUCHO, I.M.; COUTINHO, J.A. Biosurfactants from yeasts: characteristics, production and application. Advances in Experimental Medicine and Biology, v.672, p.236-249, 2010. DOI: 10.1007/978-1-4419-5979-9_18

AMÉZCUA-VEGA, C.; POGGI-VARALDO, H.M.; ESPARZA-GARCÍA F.; RÍOS-LEAL, E.; RODRÍGUEZ-VÁZQUEZ, R. Effect of culture conditions on fatty acids composition of a biosurfactant produced by Candida ingens and changes of surface tension of culture media. Bioresource Technology, v.98, n.1, p.237-240, 2007. DOI: $10.1016 /$ j.biortech.2005.11.025

ANDRADE, R.F.S.; ANTUNES, A.A.; LIMA, R.A.; ARAÚJO, H.W.C.; RESENDE-STOIANOFF, M.A.; FRANCO, L.O.; CAMPOS-TAKAKI, G.M. Enhanced Production of a Glycolipid Biosurfactant produced by Candida glabrata UCP/WFCC 1556 for Application in Dispersion and Removal of Petroderivatives. International Journal of Current Microbiology and Applied Sciences, v.4, n.7, p.563-576, 2015.

ANTUNES, A.A.; ARAÚJO, H.W.C.; ALVES DA SILVA, C.A.; ALBUQUERQUE, C.D.C.; CAMPOS-TAKAKI, G.M. Biosurfactant production by Chromobacterium violaceum ATCC 12472 using corn steep liquor and corn post-frying oil as nutrientes. Arquivos do Instituto Biológico, v.80, n.3, p.334-341, 2013. DOI: 10.1590/ S1808-16572013000300011

BAHIA, F.M.; DE ALMEIDA, G.C.; DE ANDRADE, L.P.; CAMPOS, C.G.; QUEIROZ, L.R.; DA SILVA, R.L.V.; ABDELNUR, P.V.; CORRÊA, J.R.; BETTIGA, M.; PARACHIN, N.S. Rhamnolipids production from sucrose by engineered Saccharomyces cerevisiae. Scientific Reports, v.8, p.1-10, 2018. DOI: 10.1038/ s41598-018-21230-2

BANAT, I.M.; MAKKAR, R.S.; CAMEOTRA, S.S. Potential commercial applications of microbial surfactants. Applied Microbiology Biotechnology, v.53, n.5, p.495-508, 2000.

BANAT, I.M.; FRANZETTI, A.; GANDOLFI, I.; BESTETTI, G.; MARTINOTTI, M.G.; FRACCHIA, L.; SMYTH, T.J.; MARCHANT, R. Microbial biosurfactants production, applications and future potential. Applied Microbiology Biotechnology, v.87, p.427-444, 2010. DOI: 10.1007/s00253-010-2589-0.

BANAT, I.M.; SATPUTE, S.K.; CAMEOTRA, S.S.; PATIL, R.; NYAYANIT, N.V. Cost effective technologies and renewable substrates for biosurfactants' production. Frontiers in Microbiology, v.5, p.697, 2014. DOI: $10.3389 /$ fmicb.2014.00697
BATRAKOV, S.G.; KONOVA, I.V.; SHEICHENKO, V.I.; GALANINA, L.A. Glycolipids of the filamentous fungus Absidia corymbifera F-295. Chemistry and Physics of Lipids, v.123, n.2, p.157-164, 2003. Available from: https://www.eurekamag.info/ research/010/721/010721278.php. Accessed on: Apr. 032017.

BHARDWAJ, G.; CAMEOTRA, S.S.; CHOPRA, H.K. Biosurfactants from fungi: a review - Petroleum \& Environmental Biotechnology, v.4, n.6, p.1-6, 2013. DOI: $10.4172 / 2157-7463.1000160$

BHATTACHARYA, B.; GHOSH, T.K.; DAS, N. Application of bio-surfactants in cosmetics and pharmaceutical industry. Scholars Academic Journal Pharmacy, v.6, n.7, p.320-329, 2017. DOI: $10.3390 /$ ijms 150712523

BOUASSIDA, M.; GHAZALA, I.; ELLOUZE-CHAABOUNI, S.; GHRIBI, D. Improved Biosurfactant production by Bacillus subtilis SPB 1 mutant obtained by random mutagenesis and its application in enhanced oil recovery in a sand system. Journal Microbiology Biotechnology, v.28, n.1, p.95-104, 2018. DOI: 10.4014/ jmb. 1701.01033

CALVO, C.; MANZANERA, M.; SILVA-CASTRO, G.A.; UAD, I.; GONZÁLEZ-LÓPEZ, J. Application of bioemulsifiers in soil oil bioremediation processes. Future prospects. Science of the Total Environment, v.407, n.12, p.3634-3640, 2009. DOI: 10.1016/j. scitotenv.2008.07.008

CAMERON, D.R.; COOPER, D.G.; NEUFELD, R.J. The mannoprotein of Saccharomyces cerevisiae is an effective bioemulsifier. Applied Environmental Microbiology, v.54, n.6, p.1420-1425, 1988.

CAMPOS-TAKAKI, G.M.; SARUBBO, L.A.; ALBUQUERQUE, C.D. Environmentally friendly biosurfactants produced by yeasts. Advances in Experimental Medicine and Biology, v.672, p.250-260, 2010.

CASAS, J.; OCHOA, F.G. Sophorolipid production by Candida bombicola: medium composition and culture methods. Journal of Bioscience and Bioengineering, v.88, n.5, p. 488-494, 1999. DOI: $10.1016 / \mathrm{S} 1389-1723(00) 87664-1$

CASTIGLIONI, L.G; BERTOLIN, T.E; COSTA, J.A. Produção de biossurfactantes por Aspergillus fumigatus utilizando resíduos agroindustriais como substrato. Química Nova, v.32, n.2, p.292-295, 2009. DOI: 10.1590/SO100-40422009000200005.

CASTILLO-MÉNDEZ, L.; PRIETO-CORREA, E.; JIMÉNEZ-JUNCA, C. Identification of fungi isolated from banana rachis and characterization of their surface activity. Applied Microbiology, v.64, n.3, p.246-251, 2017. DOI: 10.1111/lam.12712.

CAVALCANTI, R.M.F.; SILVA, D.P.D.S.; PAZ, M.C.F.; QUEIROZ, J.C.F. Screening, production and characterization of biosurfactants from Caatinga's filamentous fungi. International Journal Pharmaceutical Science Invention, v.6, n.5, p.23-28, 2017.

CAVALERO, D.A.; COOPER, D.G. The effect of medium composition on the structure and physical state of sophorolipids produced by Candida bombicola ATCC 22214 . Journal of Biotechnology, v.103, n. 1, p.31-41, 2003. DOI: 10.1016/SO 168-1656(03)00067-1 
CHEN, J.; HUANG, P.T.; ZHANG, K.Y.; DING, F.R. Isolation of biosurfactant producers, optimization and properties of biosurfactant produced by Acinetobacter sp. from petroleum-contaminated soil. Journal of Applied Microbiology, v.112, n.4, p.660-671, 2012. DOI: 10.1111/j.1365-2672.2012.05242.x

CIRIGLIANO, M.C.; CARMAN, G.M. Isolation of a bioemulsifier from Candida lipolytica. Applied Environmental Microbiology, v.48, n.4, p.747-750, 1984.

CIRIGLIANO, M.C.; CARMAN, G.M. Purification and characterization of liposan, a bioemulsifier from Candida lipolytica. Applied Environmental Microbiology, v.50, n.4, p.846-850, 1985.

COOPER, D.G.; PADDOCK, D.A. Torulopsis petrophilum and Surface Activity. Applied Environmental Microbiology, v.46, n.6, p. 1426-1429, 1983.

DESAI, J.D.; BANAT, M. Microbial production of surfactants and their commercial potential. Microbiology and Molecular Biology Reviews, v.61, n.1, p.47-64, 1997.

FONTES, G.C.; AMARAL, P.F.F.E.; COELHO, M.A.Z. Produção de biossurfactante por levedura. Química Nova, v.40, p.316-323, 2008. DOI: $10.1590 /$ SO $100-40422008000800033$

FONTES, G.C.; RAMOS, N.M.; AMARA, P.F.F.; NELE, M.; COELHO, M.A.Z. Renewable resources for biosurfactant production by Yarrowia lipolytica. Brazilian Journal of Chemical Engineering, v.29, n.3, p.483-493, 2012. DOI: 10.1590/ S0104-66322012000300005

FUKUOKA, T.; MORITA, T.; KONISH, M.; IMURA, T.; KITAMOTO, T. Characterization of new glycolipid biosurfactants, tri-acylated mannosylerythritol lipids, produced by Pseudozyma yeasts. Biotechnology Letters, v.29, n.7, p.1111-1118, 2007a. DOI: $10.1007 / \mathrm{s} 10529-007-9363-0$

FUKUOKA, T.; MORITA, T.; KONISH, M.; IMURA, T.; KITAMOTO, T. Structural characterization and surface-active properties of a new glycolipid biosurfactant, mono-acylated mannosylerythritol lipid, produced from glucose by Pseudozyma antarctica. Applied Microbiology Biotechnology, v.76, p.810-810, 2007b. DOI: 10.1007/s00253-007-1051-4

GALAFASSI, S.; CUCCHETTI, D.; PIZZA, F., FRANZOSI, G.; BIANCHI, D.; COMPAGNO, C. Lipid production for second generation biodiesel by the oleaginous yeast Rhodotorula graminis. Bioresource Technology, v.111, p.398-403, 2012. DOI: $10.1016 / \mathrm{j}$. biortech.2012.02.004

GAUTAM, G.; MISHRA, V.; VERMA, P.; PANDEY, A.K.; NEGI, S. A Cost Effective Strategy for Production of Bio-surfactant from Locally Isolated Penicillium chrysogenum SNP5 and its Applications. Journal of Bioprocessing and Biotechniques, v.4, n.6, p. 1-7, 2014. DOI: $10.4172 / 2155-9821.1000177$

GONG, Z.; SHEN, H.; ZHOU, W.; WANG, Y.; YANG, X.; ZHAO, Z.K. Efficient conversion of acetate into lipids by the oleaginous yeast Cryptococcus curvatus. Biotechnology Biofuels, v.8, p.1, 2015.

HOMMEL, R.K.; WEBER, L.; WEISS, A.; HIMMELREICH, U.; RILKE, O.; KLEBER, H.-P. Production of sophorose lipid by Candida (Torulopsis) apicola grown on glucose. Journal of Biotechnology, v.33, n.2, p.147-155, 1994. DOI: 10.1016/0168-1656(94)90107-4

HUA, Z.; CHEN, J.; LUN, S.; WANG, X. Influence of biosurfactants produced by Candida antarctica on surface properties of microorganism and biodegradation of n-alkanes. Water Research, v.37, n.17, p.4143-4150, 2003. DOI: 10.1016/ S0043-1354(03)00380-4

JAMAL, P.; NAWAWI, W.; NAWAWI, W.M.F.W.; ALAM, Z. Optimum medium components for biosurfactant production by Klebsiella pneumoniae WMFO2 utilizing sludge palm oil as a substrate. Australian Journal of Basic and Applied Sciences, v.6, n. 1, p. $100-108,2012$.

KAKUGAWA, K.; TAMAI, M.; IMAMURA, K.; MIYAMOTO, K.; MIYOSHI, S.; MORINAGA, Y.; SUZUKI, O.; MIYAKAWA, T. Isolation of yeast Kurtzmanomyces sp. I-11, novel producer of mannosylerythritol lipid. Bioscience Biotechnology Biochemistry, v.66, n.1, p.188-191, 2002. DOI: 10.1271/ bbb.66.188

KALYANI, A.L.T.; SIREESHA, G.N.; SANKAR, G.G.G.; PRABHAKAR, $\mathrm{T}$. Isolation of bio-surfactant producing actinomycetes from terrestrial and marine soils. International Journal of Pharmaceutical Sciences and Research, v.5, n.9, p.4015, 2014. DOI: 10.13040/ IJPSR.0975-8232.5(9).4015-22

KANNAHI, M.; SHERLEY, M. Biosurfactant production by Pseudomonas putida and Aspergillus Níger from oil contaminated site. International Journal Chemical and Pharmaceutical Sciences, v.3, n.4, p.37-43, 2012.

KATEMAI, W. Biosurfactants from Yeasts: characteristics, production and application. Walailak Journal of Science and Technology, v.9, n.1, p.1-8, 2012.

KATEMAI, W.; MANEERAT, S.; KAWAI, F.; KANZAKI, H.; NITODA, T.; $\mathrm{H}-\mathrm{KITTIKUN}$, A. Purification and characterization of a biosurfactant produced by Issatchenkia orientalis SR4. The Journal of General and Applied Microbiology, v.54, n. 1, p.79-82, 2008.

KARATAY, S.E.; DÖNMEZ, G. Improving the lipid accumulation properties of the yeast cells for biodiesel production using molasses. Bioresource Technology, v. 101, p.7988-7990, 2010. DOI: $10.1016 /$ j.biortech.2010.05.054.

KIM, H.S.; JEON, J.W.; KIM, B.H.; AHN, C.Y.; OH, H.M.; YOON, B.D. Extracellular production of a glycolipid biosurfactant, mannosylerythritol lipid, by Candida sp. SY 16 using fed-batch fermentation. Applied Microbiology Biotechnology, v.70, n.4, p.391-396, 2006. DOI: 10.1007/s00253-005-0092-9

KIM, H.-S.; JEON, J.-W.; KIM, S.-B.; OH, H.-M.; KWON, T.-J.; YOON, B.-D. Surface and physico-chemical properties of a glycolipid biosurfactant, mannosyl erythritol lipid, from Candida antarctica. Biotechnology Letters, v.24, n. 19, p.1637-1641, 2002.

KIRAN, G.S.; HEMA, T.A.; GANDHIMATHI, R.; SELVIN, J.; THOMAS, T.A.; RAVJI, T.R.; NATARAJASEENIVASAN K. Optimization and production of a biosurfactant from the sponge-associated marine fungus Aspergillus ustus MSF3. Colloids and Surfaces B: Biointerfaces, v.73, n.2, p.250-256, 2009. DOI: 10.1016/j. colsurfb.2009.05.025. 
KITAMOTO, D.; IKEGAMI, T.; SUZUKI, G.T.; SASAKI, A.; TAKEYAMA, Y.; IDEMOTO, Y.; KOURA, N.; YANAGISHITA, H. Microbial conversion of n-alkanes into glycolipid biosurfactants, mannosylerythritol lipids, by Pseudozyma (Candida antarctica). Biotechnology Letters, v.23, n.20, p. 1709-1714, 2001.

KOMA, D.; HASUMI, F.; YAMAMOTO, E.; OHTA, T.; CHUNG, S.Y.; KUBO, M. Biodegradation of long-chain n-paraffins from waste oil of car engine by Acinetobacter sp. Journal of Bioscience and Bioengineering, v.91, n.1, p.94-96, 2001. DOI: 10.1016/ S1389-1723(01)80120-1

KONISHI, M.; FUKUOKA, T.; MORITA, T.; IMURA, T.; KITAMOTO, D. Production of new types of sophorolipids by Candida batistae. Journal of Oleo Science, v.57, n.6, p.359-369, 2008. DOI: $10.5650 /$ jos.57.359

KOSARIC, N. Biosurfactants and Their Application for Soil Bioremediation. Food Technology and Biotechnology, v.39, n.4, p.295-304, 2001.

KREPSKY, N.I.; DA SILVA, F.S.I.; FONTANA, L.F.I.; CRAPEZ, M.A.C. Alternative methodology for isolation of biosurfactant-producing bacteria. Brazilian Journal Biology, v.67, n. 1, p.1 17-124, 2007. DOI: $10.1590 / S 1519-69842007000100016$

LANCIOTTI, R.; GIANOTTI, A.; BALDI, D.; ANGRISANI, R. SUZZI, G.; MASTROCOLA, D.; GUERZONI, M.E. Use of Yarrowia lipolytica strains for the treatment of olive mill wastewater. Bioresource Technology, v.96, n.3, p.317-322, 2005. DOI: 10.1016/j. biortech.2004.04.009

LIMA, J.M.S.; PEREIRA, J.O.; BATISTA, I.H.; COSTA NETO, P.Q.; DOS SANTOS, J.C.; ARAÚJO, S.P.; PANTOJA, M.C.; MOTA, A.J.; AZEVEDO, J.L. Potential biosurfactant producing endophytic and epiphytic fungi, isolated from macrophytes in the Negro River in Manaus, Amazonas, Brazil. African Journal Biotechnology, v.15, n.24, p.1217-1223, 2016. DOI: $10.5897 / A J B 2015.15131$

LIMA, R.A.; RODRIGUEZ, D.M.; ANDRADE, R.F.S.; TAKAI, G.C. Production and characterization of biosurfactant isolated from Candida glabrata using renewable substrates. African Journal of Microbiology Research, v.1 1, n.6, p.237-244, 2017. DOI: $10.5897 / A J M R 2016.8341$

LINS, A.B.; BIONE, A.P.; FONSECA, T.C.S.; SILVA, T.C.; ANDRADE, R.F.S.; CAMPOS-TAKAKI, G.M. Biosurfactant production by Cunninghamella phaeosphora UCP 1303 using controlled temperature through of arduino. International Journal of Current Microbiology and Applied Sciences, v.6, n. 12, p.2708-27 15, 2017. DOI: 10.20546/ijcmas.2017.612.314

LIU, Y.; KOH, C.M.J.; JI, L. Bioconversion of crude glycerol to glycolipids in Ustilago maydis. Bioresource Technology, v.102, n.4, p.3927-3933, 2011. DOI: 10.1016/j.biortech.2010.11.115

LUKONDEH, T.; ASHBOLT, N.J.; ROGERS, P.L. Evaluation of Kluyveromyces marxianus as a source of yeast autolysates. Journal of Industrial Microbiology and Biotechnology, v.30: 52-56. DOI 10.1007/s10295-002-0008-y.

LUNA, J.M.; SARUBBO, L.A.; CAMPOS-TAKAKI, G.M. A new biosurfactant produced by Candida glabrata UCP 1002 : characteristics of stability and application in oil recovery. Brazilian Archives of Biology and Technology, v.52, n.4, p.785-793, 2009. DOI: $10.1590 /$ S1516-8913200900040000

LUNA, J.M.; RUFINO, R.D.; SARUBBO, L.A.; CAMPOS-TAKAKI, G.M. Characterisation, surface properties and biological activity of a biosurfactant produced from industrial waste by Candida sphaerica UCPO995 for application in the petroleum industry. Colloids Surface and Interface B, v.102, p.202-209, 2013. DOI: $10.1016 /$ j.colsurfb.2012.08.008

MORITA, T.; KONISHI, M.; FUKUOKA, T.; IMURA, T.; KITAMOTO, H.K.; KITAMOTO, D. Characterization of the genus Pseudozyma by the formation of glycolipid biosurfactants, mannosylerythritol lipids. FEMS Yeast Research, v.7, n.2, p.286-292, 2007. DOI: $10.1111 /$ j.1567-1364.2006.00154.x

MOSSA, T.A.A.; AHMED, G.M.; ABDEL-HAMID, S.M.S. Optimization of cultural conditions for biosurfactant production from Nocardia amarae. Journal of Applied Sciences Research, v.2, n. 11 , p.844-850, 2006.

MUTHUSAMY, K.; GOPALAKRISHNAN, S.; KOCHUPAPPY RAVI, T.; SIVACHIDAMBARAM, P. Biosurfactants: properties, commercial production and application. Current Science, v.94, n.6, 736-p.746, 2008.

NITSCHKE, M.; PASTORE, G.M. Biossurfactantes: propriedades e aplicações. Química Nova, São Paulo, v.25, n.5, p.772-776, 2002. DOI: 10.1590/SO100-40422002000500013

OCHSNER, U.A.; KOCH, A.K.; FIECHTER, A.; REISER, J. Isolation and characterization of a regulatory gene affecting rhamnolipid biosurfactant synthesis in Pseudomonas aeruginosa. Journal of bacteriology, v.176, n.7, p.2044-2054, 1994. DOI: 10.1128/ jb.176.7.2044-2054.1994

PACWA-PLOCINICZAK, M.; PLAZA, G.A.; PIOTROWSKA SEGET, Z.; CAMEOTRA, S.S. Environmental applications of biosurfactants: Recent Advances. International Journal of Molecular Sciences, v.12, n. 1, p.633-654, 201 1. DOI: 10.3390/ijms 12010633

PAPANIKOLAOU, S.; CHEVALOT, I.; KOMAITIS, M.; MARC, I.; AGGELIS, G. Single cell oil production by Yarrowia lipolytica growing on an industrial derivative of animal fat in batch cultures. Applied. Microbiology Biotechnology, v.58, p.308-312, 2002. DOI: 10.1007/s00253-001-0897-0

PELE, M.A.; MONTERO-RODRIGUEZ, D.; RIBEAUX, D.R.; SOUZA, A.F.; LUNA, M.A.C.; SANTIAGO, M.F.; ANDRADE, R.F.S.; SILVA, T.A.L.; SANTIAGO, A.L.C.M.A.; CAMPOS-TAKAK, G.M. Development and improved selected markers to biosurfactant and bioemulsifier production by Rhizopus strains isolated from Caatinga soil. African Journal of Biotechnology, v.17, n.6, p.150-157, 2018. DOI: $10.5897 / A J B 2017.16230$

PERFUMO, A.; BANAT, I.M.; MARCHANT, R. Going Green and Cold: Biosurfactants from Low-Temperature Environments to Biotechnology Applications. Trends in biotechnology, v.36, n.3, p.277-289, 2018. DOI: 10.1016/j.tibtech.2017.10.016

PRADHAN, A.K. A bioactive microbial compound having various biotechnological activities: biosurfactant. Journal Bacteriology and Infectious Diseases, v. 1, n.1, 1-2, 2017. 
QAZI, M.A.; KANWA, T.; JADOON, M.; AHMED, S.; FATIMA, N. Isolation and characterization of a biosurfactant-producing Fusarium sp. BS-8 from oil contaminated soil. Biotechnology Progress, v.30, n.5, p.1065-1075, 2014. DOI: 10.1002/ btpr.1933.

RAJESH, M.; SAMUNDEESWARI, M.; ARCHANA, B. Isolation of Biosurfactant Producing Bacteria from Garbage Soil. Journal Applied \& Environmental Microbiology, v.5, n.2, p. 74-78, 2017. DOI: $10.12691 /$ jaem-5-2-3

RAU, U.; NGUYEN, L.A.; ROEPER, H.; KOCH, H.; LANG, S. Downstream processing of mannosylerythritol lipids produced by Pseudozyma aphidis. European Journal of Lipid Science and Technology, v.107, n.6, p.373-380, 2005. DOI: 10.1002/ ejlt.200401122

ROCHA E SILVA, N.M.P.; RUFINO, R.D.; LUNA, J.M.; SANTOS, V.A.; SARUBBO, L.A. Screening of Pseudomonas species for biosurfactant production using low-cost substrates. Biocatalise Agriculture Biotechnology, v.3, p.132-139, 2014. DOI: 10.1016/j. bcab.2013.09.005

ROELANTS, S.L.; SAERENS, K.M.; DERYCKE, T.; LI, B.; LIN, Y.C.; VAN DE PEER, Y.; DE MAESENEIRE, S.L.; VAN BOGAERT, I.N.; SOETAERT, W. Candida bombicola as a platform organism for the production of tailor-made biomolecules. Biotechnology of Bioengineering, v.1 10, n.9, p. 2494-503, 2013. DOI: 10.1002/ bit.24895

RUFINO, R.D.; LUNA, J.M.; CAMPOS-TAKAKI, G.M.; SARUBBO, L.A. Characterization and properties of the biosurfactant produced by Candida lipolytica UCP 0988. Electronic Journal of Biotechnology, v.17, n.1, 2014. DOI: 10.1016/j.ejbt.2013.12.006

RUFINO, R.D.; LUNA, J.M.; SARUBBO, L.A.; RODRIGUES, L.R.M.; TEXEIRA, J.A.C.; CAMPOS-TAKAKI, G.M. Antimicrobial and anti-adhesive potential of a biosurfactant Rufisan produced by Candida lipolytica UCP 0988. Colloids Surfurface and Inteface B, v.84, p.1-5, 2011 . DOI: $10.1016 / \mathrm{j}$. colsurfb.2010.10.045

SAENGE, C.; CHEIRSILP, B.; SUKSAROGE, T.T; BOURTOOM, T. Potential use of oleaginous red yeast Rhodotorula glutinis for the bioconversion of crude glycerol from biodiesel plant to lipids and carotenoids. Process Biochemistry, v.46, p.210-218, 2011. DOI: $10.1016 /$ j.procbio.2010.08.009

SARUBBO, L.A.; FARIAS, C.B.; CAMPOS-TAKAKI, G.M. Co-Utilization of Canola Oil and Glucose on the Production of a Surfactant by Candida lipolytica. Current Microbiology, v.54, n. 1, p.68-73, 2007. DOI: $10.1007 / \mathrm{s} 00284-006-0412-z$

SARUBBO, L.A.; MARÇAL, M.C.; NEVES, M.L.C.; SILVA, M.P.C.; PORTO, A.L.F.; CAMPOS-TAKAKI, G.M. Bioemulsifier production in batch culture using glucose as carbon source by Candida lipolytica. Applied Biochemistry Biotechnology, v.95, n. 1, p.59-67, 2001. DOI: 10.1385/ABAB:95:1:59

SARUBBO, L.A.; LUNA, J.M.; CAMPOS-TAKAKI, G.M. Production and stability studies of the bioemulsifier obtained from a new strain of Candida glabrata UCP 1002. Electronic Journal of Biotechnology, v.9, n.4, p.400-406, 2006. DOI: 10.4067/ S0717-34582006000400008
SHEPERD, R.; ROCKEY, J.; SUTHERLAND, I.W.; ROLLER, S. Novel bioemulsifiers from microorganisms for use in foods. Journal of Biotechnology, v.40, n.3, p.207-217, 1995. DOI: 10.1016/0168-1656(95)00053-S

SILVA, N.R.A.; LUNA, M.A.; SANTIAGO, A.L.; FRANCO, L.O.; SILVA, G.K.; DE SOUZA, P.M.; OKADA, K.; ALBUQUERQUE, C.D.; DA SILVA, C.A.; CAMPOS-TAKAKI, G.M. Biosurfactant-and-Bioemulsifier Produced by a Promising Cunninghamella echinulata isolated from Caatinga Soil in the Northeast of Brazil. International Journal of Molecular Sciences, v.15, n.9, p. 15377-15395, 2014. DOI: $10.3390 /$ ijms 150915377.

SILVA, G.K.B.; NEGREIROS, J.M.; SILVA, N.R.A.; SILVA, T.A.L.E.; BARBOSA, R.N.; OLIVEIRA, N.T.; OKADA, K.; CAMPOS-TAKAKI, G.M. Characterization of Aspergillus niger isolated from Caatinga soil with potential of biosurfactant production. In: MÉNDEZ-VILAS, A. (Org.). Industrial, Medical and Environmental Applications of Microorganisms Current Status and Trends. Madrid: eBookstore, 2015. p.65-69. DOI: 10.3390/ijms 150915377.

SINGH, M.; DESAI, J.D. Hydrocarbon emulsification by Candida tropicalis and Debaryomyces polymorphus. Indian Journal of Experimental Biology, v.27, n.3, p.224-226, 1989.

SOBRINHO, H.B.S.; RUFINO, R.D.; LUNA, J.M.; SALGUEIRO, A.A.; CAMPOS-TAKAKI, G.M.; LEITE, L.F.C.; SARUBBO, L.A. Utilization of two agroindustrial by-products for the production of a surfactant by Candida sphaerica UCP0995. Process Biochemistry, v.43, n.9, p.912-917, 2008. DOI: 10.1016/j.procbio.2008.04.013

SOLAIMAN, D.K.; ASHBY, R.D.; NUÑEZ, A.; FOGLIA, T.A. Production of sophorolipids by Candida bombicola grown on soy molasses as substrate. Biotechnology Letters, v.26, n.15, p.1241-1245, 2004. DOI: 10.1023/B:BILE.0000036605.80577.30

SOUZA, A.F.; RODRIGUEZ, D.M.; RIBEAUX, D.R.; LUNA, M.A.; LIMA E SILVA, T.; ANDRADE, R.F.; GUSMÃO, N.B.; CAMPOS-TAKAKI, G.M. Waste Soybean Oil and Corn Steep Liquor as Economic Substrates for Bioemulsifier and Biodiesel Production by Candida lipolytica UCP 0998. International Journal of Molecular Science, v.17, n. 10 , p.1608-1626, 2016. DOI: 10.3390\%2Fijms 17101608

SOUZA, K.S.T.; GUDIÑA, E.J.; AZEVEDO, Z.; FREITAS, V.; SCHWANA, R.F.; RODRIGUES, L.R.; DIAS, D.R.; TEIXEIRA, J.A. New glycolipid biosurfactants produced by the yeast strain Wickerhamomyces anomalus CCMA 0358. Colloids and Surfaces B: Biointerfaces, v. 154, p.373-382, 2017. DOI: 10.1016/j.colsurfb.2017.03.041

SOUZA, P.M.; SILVA, T.A.L.; FREITAS-SILVA, M.C.; ANDRADE, R.F.S.; LIMA, M.A.B.; SILVA, P.H.; FONSECA, T.C.S.; CAMPOS-TAKAKI, G.M. Factorial Design based Medium Optimization for the Improved Production of Biosurfactant by Mucor polymorphosphorus. International Journal of Current Microbiology and Applied, v.5, n. 1 1, p.898-905, 2016. DOI: 10.20546/ijcmas.2016.511.103

Production of Tensioactive Compound using Waste Soy Oil and Corn Steep Liquor by Mucoralean fungus Cunninghamella bertolletiae. International Journal of Current Microbiology and Applied Science, v.6, n.12, p.2728-2737, 2017. DOI: 10.20546/ ijcmas.2017.612.316

SYLDATK, C.; WAGNER, F. Biosurfactants and Biotechnology, Marcel Dekker: New York, cap. 3, 1987. 
THANOMSUB, B.; WATCHARACHAIPONG, T.; CHOTELERSAK, K.; ARUNRATTIYAKORN, P.; NITODA, T.; KANZAKI, H. Monoacylglycerols: glycolipid biosurfactants produced by a thermotolerant yeast, Candida ishiwadae. Journal of Applied Microbiology, v.96, n.3, p.588-592, 2004. DOI: $10.1111 /$ j.1365-2672.2004.02202.x

TULLOCH, A.P.; SPENCER, J.F.T.; DEINEMA, M.H. A new hydroxy fatty acid sophoroside from Candida bogoriensis. Canadian Journal of Chemistry, v.46, n.3, p.345-348, 1968. DOI: 10.1139/v68-057

VANCE-HARROP, M.H.; GUSMÃO, N.B.; CAMPOS-TAKAKI, G.M. NeW bioemulsifiers produced by Candida lipolytica using D-glucose and babassu oil as carbon sources. Brazilian Journal of Microbiology,
São Paulo, v.34, n.2, p. 120-123, 2003. DOI: 10.1590/ S1517-83822003000200006

ZINJARDE, S.; CHINNATHAMBI, S.; LACHKE, A.H.; PANT, A. Isolation of an emulsifier from Yarrowia lipolytica NCIM 3589 using a modified mini isoelectric focusing unit. Applied Microbiology, v.24, n.2, p.117-121, 1997. DOI: 10.1046/j.1472-765X.1997.00355.x

YOON, S.H.; RHEE, J.S. Lipid from yeast fermentation: Effects of cultural conditions on lipid production and its characteristics of Rhodotorula glutinis. Journal of the American Oil Chemists' Society, v.60, n.7, p.1281-1286, 1983. 